\title{
Delayed and Overlooked Diagnosis of an Unusual Opportunistic Infection in a Renal Transplant Recipient: Visceral Leishmaniasis
}

\author{
Böbrek Nakilli Hastada Az Görülen Fırsatçı Enfeksiyonun Geciken ve Gözden Kaçırılan
}

Tanısı: Visseral Leishmaniasis

\section{Ayşegül ZÜMRÜTDAL ${ }^{1}$, Ertuğrul ERKEN¹, Tuba TURUNÇ², Şule ÇOLAKOĞLU³, Yusuf Ziya DEMIROĞLU², Rüya ÖZELSANCAK', Soner SOLMAZ4}

${ }^{1}$ Department of Nephrology, Adana Training and Research Center, Başkent University, Adana

2Department of Infectious Diseases and Clinical Microbiology, Adana Training and Research Center, Başkent University, Adana

${ }^{3}$ Department of Microbiology and Clinical Microbiology, Adana Training and Research Center, Başkent University, Adana

${ }^{4}$ Department of Hematology, Adana Training and Research Center, Başkent University, Adana, Turkey

\begin{abstract}
Visceral leishmaniasis is a rare opportunistic infection in renal transplantation patients and its presentation may be associated with or masked by many other factors in immunosuppressed patients. So, if it is not searched for in particular, diagnosis may be easily overlooked or delayed in renal transplant patients. A 32-year-old renal transplant recipient devoleped splenomegaly, pyrexia and pancytopenia. Six months after the first bone marrow examination, the delayed diagnosis was made possible by a second bone marrow aspiration. Liposomal amphotericin B was effective in his treatment although he had a recurrence. Early diagnosis of visceral leishmaniasis is crucial for the renal transplant recipient's therapy; and even in treated patients, the mortality rate may be high. In our case, although the time up to diagnosis was as long as six months after the onset of symptoms, response to treatment was satisfactory with higher doses of liposomal amphotericin $\mathrm{B}$ in the second cycle. Also, in the short term, the rate of recurrence was comparable to other reported patients who were diagnosed and treated in a month. (Turkiye Parazitol Derg 2010; 34: 183-5)
\end{abstract}

Key Words: Renal transplantation, visceral leishmaniasis, pancytopenia, fever, hepatosplenomegaly

Received: 29.09.2010

Accepted: 24.12 .2010

\section{ÖZET}

Visseral leishmaniazis böbrek nakilli hastalarda seyrek görülen bir fırsatçı enfeksiyondur ve hastalık immünsüprese hastalarda pek çok farklı duruma eşlik edebilir ya da maskelenebilir. Dolayısıyla, özellikle araştııılmaz ise bu tanı böbrek nakilli hastalarda kolayca gözden kaçabilir ya da gecikebilir. 32 yaşında böbrek nakilli erkek hasta splenomegali, ateş ve pansitopeni ile başvurdu. Gecikmiş tanı, ilk kemik iliği incelemesinden 6 ay sonra yapılan ikinci kemik iliği aspirasyonu ile mümkün olabildi. Hastada bir kez rekürrens gözlenmesine rağmen Lipozomal Amfoterisin B, tedavide etkiliydi. Böbrek nakilli hastalarda visseral leishmaniazisin erken tanısı çok önemlidir, tedavi edilen hastalarda bile ölüm oranı oldukça yüksek olabilir. Bizim olgumuzda hastalığın tanısı semptomların başlamasından 6 ay kadar geç bir sürede konmuş olsa da, tedaviye yanıt ikinci kez daha yüksek dozlarda verilen Amfoterisin B ile yeterli olmuştur. Kısa dönemde ise, rekürrens bir ay içinde tanısı konulan ve tedavi verilen hastalar ile benzerdi. (Turkiye Parazitol Derg 2010; 34: 183-5)

Anahtar Sözcükler: Böbrek nakli, visseral leishmaniasis, pansitopeni, ateş, hepatosplenomegali

Geliş Tarihi: 29.09.2010

Kabul Tarihi: 24.12 .2010

Address for Correspondence/Yazışma Adresi: Dr. Ayşegül Zümrütdal, Başkent Üniversitesi Adana Uygulama ve Araştırma Merkezi, Nefroloji Anabilim Dalı, Adana, Turkey Phone: +90 3223272727 E-mail: azumrutdal@yahoo.com

doi:10.5152/tpd.2010.09 


\section{INTRODUCTION}

Infections are an important cause of morbidity and mortality in post-renal transplant patients. Visceral leishmaniasis (VL) is a well recognized but uncommon opportunistic infection in immunosuppressed patients, even in endemic areas. However, the number of published cases has quadrupled since the beginning of the 1990s (1). To our knowledge, to date there have been nearly 60 reported renal transplant cases with VL. So, the clinical aspects, diagnostic problems and response to treatment can be evaluated more clearly in this group of patients during the last 20 years than was possible before.

Most cases have been observed in patients living in the countries of the Mediterranean basin. VL has long been known to exist in the western and southeastern parts of Turkey and it may be an important public health problem throughout the country. However, the definite incidence and prevalence of the disease have not yet been establishedt. It is most commonly associated with kidney transplantation, and cases are also recorded among patients undergoing liver, heart, lung, pancreas and bone marrow transplantation. Most patients with subclinical infection harbor lifelong viable parasites and can develop reactivation disease if immunosuppression occurs. If not adequately diagnosed and treated, it can be fatal $(1,2)$. However, based on our case and the reported cases in the literature, the diagnosis is often overlooked or delayed in renal transplant patients $(1,3,4)$. We report such a case, whose delayed diagnosis was made possible by a second bone marrow examination after 6 months.

\section{CLINICAL PRESENTATION}

In September 2009, a 32-year-old renal transplant recipient, a resident of the southern part of Turkey, Adana, which is an endemic zone for the disease, was admitted to our hospital with fever, cough and malaise. Physical examination revealed a pale, febrile $\left(39^{\circ} \mathrm{C}\right)$ patient with no significant lymphadenopathy. He was normotensive, cardiac examination was normal, fine ralles were present in the lower parts of the lungs, and there was massive splenomegaly. Past medical history included bronchiectasis with recurrent pneumonia in his childhood and right lung lower lobectomy in 1999. In 2000, he was on renal replacement therapy with a diagnosis of chronic renal failure due to chronic sclerosing glomerulonephritis. In 2004, he received a kidney transplant from a living related donor. He had recurrent pneumonia episodes 3 or 4 times a year, during his follow-up as a renal transplant recipient. Also, his basal serum creatinine and hemoglobin levels were between 1.8-2.4 mg/dL (0.3-1.4 mg/dL) and 10.5-11.5 $\mathrm{gr} / \mathrm{dL}$ (12-14 $\mathrm{gr} / \mathrm{dL})$, respectively, after renal transplantation.

Laboratory studies on admission showed the following values: blood urea nitrogen $23 \mathrm{mg} / \mathrm{dL}(7-25 \mathrm{mg} / \mathrm{dL})$, serum creatinine 2.2 $\mathrm{mg} / \mathrm{dL}$, albumin $3.3 \mathrm{~g} / \mathrm{dL}$ (3.5-5 g/dL), globulin $1.7 \mathrm{~g} / \mathrm{dL}(1.5-3.5$ $\mathrm{g} / \mathrm{dL})$, hemoglobin $8.5 \mathrm{~g} / \mathrm{dL}$, white blood cell $2.9 \times 10^{3}$ (4.50-11.0), platelet 128.000 (130.000-400.000) and CRP 85 mg/L (<3 mg/L). Urinalysis showed $0.5 \mathrm{gr} /$ day proteinuria and creatinine clearance was $46 \mathrm{ml} / \mathrm{min}$ (100-125 ml/min). Folic acid, iron and vitamin B12 levels, liver functions and coagulation tests were all normal. Abdominal ultrasonography showed an enlarged spleen of 19.5 $\mathrm{cm}$ and the liver was normal. Hepatitis, brucella, malaria, HIV tests and also blood, urine and sputum cultures were all negative. PCR for CMV, serum antibody test for leishmania by indirect fluorescent and PPD tests for tuberculosis were likewise negative. Endoscopic examination of the upper gastrointestinal system showed gastritis. Normal echocardiography ruled out endocarditis. Computerised thoraco-abdominal tomography revealed nothing specific except sequela findings, indicating his lobectomy. Bone marrow aspiration and biopsy examinations were investigated by the hematology and pathology departments and showed nonspecific findings. He was started on antibiotherapy empirically (piperacilin/ tazobactam) due to his past history of pneumonia and bronchiectasis. His immunusupressive regimen included low dose prednisolone ( $5 \mathrm{mg} /$ day), sirolimus (1×2mg/day) and mycophenolate mofetil ( $2 \times 750 \mathrm{mg} /$ day). On the $20^{\text {th }}$ day of hospitalization, although he was afebrile, he was still leucopenic $\left(2.5 \times 10^{3}\right)$. The patient became clinically stable and was discharged on the $28^{\text {th }}$ day. Mycophenolate mofetil therapy was discontinued. He was scheduled for outpatient follow-up.

He was clinically stable until November 2009, with no improvement in laboratory findings. In November, he was hospitalized with fever, malasie, cough and sputum. Leucocyte and platelet counts were further decreased (i.e. $1.8 \times 10^{3} / \mathrm{mm}^{3}$ and $84 \times 10^{3} / \mathrm{mm}^{3}$ respectively) and the spleen was enlarged to $22.5 \mathrm{~cm}$. Blood, urine and tuberculosis cultures and other infectious laboratory tests were repeated and again all of them were negative except for the sputum. Pseudomonas aureginosa was isolated from the sputum and meropenem was started at a renal dose. Filgrastim was also used to reverse leucopenia. Altough splenic aspiration was associated with a risk of hemorrhage, a liver biopsy was performed to exclude any lymphoproliferative or malignant or infectious disease. Liver biopsy exhibited only portal inflammation and centrilobular congestion. His lung symptoms had improved and he was clinically stable and afebrile. He was discharged on the $15^{\text {th }}$ day.

During the follow-up period, he had no complaints except a few short febrile episodes $\left(37.4^{\circ} \mathrm{C}\right.$ and $\left.37.7^{\circ} \mathrm{C}\right)$. His hemoglobin, leucocyte and platelet counts were $10.3 \mathrm{gr} / \mathrm{dL}, 2.4 \times 10^{3}$ and $113 \times 10^{3} /$ $\mathrm{mm}^{3}$ respectively.

In March 2010, he was admitted to the hospital once more with a similar clinical picture. Serum haemoglobin was $5.2 \mathrm{gr} / \mathrm{dl}$, leucocyte and platelet counts were $1.5 \times 10^{3}$ and $45 \times 10^{3}$ per $\mathrm{mm}^{3}$. Bone marrow aspiration, biopsy and culture specimens were repeated. This time, in bone marrow examinations, widespread extracellular amastigotes of leishmania spp. were determined with well over100 parasites per microscopic field. The culture for Leishmania was also positive in Novy-MacNeal-Nicolle (NNN). Thereafter the first bone marrow and liver biopsy specimens were re-examined for auto-control. In the prolonged re-examination of the first bone marrow slide in all fields, just a few leishmania parasites were detected which had been overlooked in the first examination. In the repeated examination, no leishmania parasites were detected in the liver biopsy.

The treatment of $V L$ in immunocompromised patients is still unclear. However, liposomal amphotericin B is the most active agent in use, with a high efficacy and low toxicity (5). Our patient was started on liposomal amphotericin B, 3mg/kg per day intra- 
venously for five days, and additional doses were administered on the $14^{\text {th }}$ and $21^{\text {st }}$ days. Treatment was substituted by allopurinol $20 \mathrm{mg} / \mathrm{kg}$ per day. His fever responded dramatically and his laboratory findings improved. Hemoglobin was $11.2 \mathrm{gr} / \mathrm{dl}$, leucocyte count was $2.7 \times 10^{3} / \mathrm{mm}^{3}$ and platelet count was $151 \times 10^{3} / \mathrm{mm}^{3}$.

Three weeks later the patient had a second febrile episode $\left(38^{\circ} \mathrm{C}\right)$. Bone marrow aspiration demonstrated leishmanial parasite infestation and the recurrence was attributed to the inadequate total dose administered during the initial treatment. The patient was retreated with $4 \mathrm{mg} / \mathrm{kg}$ per day I.V. for five days, and additional doses were given on the $10^{\text {th }}, 17^{\text {th }}, 24^{\text {th }}, 31^{\text {st }}$ and $38^{\text {th }}$ days. He suffered no side effects from this therapy. The fever and laboratory abnormalities responded in a few days. At the end of the second cycle of therapy, his hemoglobin was $11.5 \mathrm{gr} / \mathrm{dL}$, leucocyte was $4.7 \times 10^{3} / \mathrm{mm}^{3}$ and platelet count was $214 \times 10^{3} / \mathrm{mm}^{3}$. His spleen size regressed to $17.4 \mathrm{~cm}$; his serum creatinine level was $2.1 \mathrm{mg} / \mathrm{dL}$. During the three-month follow-up period he was pronounced completely cured, with no clinical or laboratory relapse. A follow-up bone marrow examination showed no parasites. The patient has been scheduled for close outpatient follow-up due to the long-term risk of recurrence.

\section{DISCUSSION}

$V L$ is characterized clinically by prolonged irregular fever, hepatosplenomegaly, weight loss and pancytopenia, and has been associated with high mortality. It is difficult to diagnose clinically in immunocompromised hosts (6). Definitive diagnosis requires the demonstration of parasite by smear or culture in tissue. However, sensitivity is limited and repeated tissue sampling may be required. Serological testing including indirect fluorescent antibody tests and enzyme-linked immunosorbent assays may also be useful diagnostic tools. However, the sensitivity and specificity of serologic assays vary depending on the antigen and format used. There may be some regional variability and they may yield false negative and positive results in immunosuppressed patients (7).

Despite the endemic distribution of $V L$ in certain parts of our country, there are only two reported cases of $V L$ in renal transplant recipients, in 1997 and $2003(8,9)$. This suggests that the disease is underdiagnosed or there are unreported cases.

From the reports of different transplant centers, VL occurred an avarage of 7.5-46.2 months after transplantation and recurrence was observed in patients with longer times from transplantation to onset of VL (3). There are also a few reports of cases in whom $V L$ occurred more than 5 years after renal transplantation, as happened in our case.

Brazil is one of the endemic countries, accounting for $90 \%$ of cases. In a review of eight Brazilian patients, bone marrow smears were positive in five of the patients (62.5\%) upon first examination, and the other patients required a second or third test to confirm the diagnosis (3). Because the number of parasites can vary widely from field to field, quantification requires careful, prolonged examination of the slide. So, diagnosis of visceral leishmaniasis should always be kept in mind in a renal transplant recipient even when serology and bone marrow smears are negative (10). Since parasites replicate in the reticu- loendothelial system, very high parasite loads accumulate in the spleen, liver and bone marrow with time. So repeated biopsies may help in cases of overlooked diagnosis of $\mathrm{VL}$.

Early diagnosis of VL is crucial for patient therapy and outcome. To the best of our knowledge, our case had one of the longest times (six months) up to diagnosis after the onset of symptoms. However, response to treatment was satisfactory with higher doses of liposomal amphotericin B in the second cycle, and the rate of recurrence in the short period was comparable to other reported patients who were diagnosed and treated in a few months.

Based on the reported cases in the literature, VL may also present atypically (without fever) in renal transplanted patients (8). Extended afebrile/subclinical periods, associated viral and/or bacterial infections, occurrence in nonendemic/low risk area and nonspecific smear/tissue examinations in the early period may contribute to the delay in the diagnosis of $V L$. The renal recipients with hematological abnormalities and organomegalies, should always be examined for VL until it is ruled out for certain with repeated diagnostic tests. Also consultation of the suspicious cases with the parazitology department may help to diagnose the disease earlier.

Publishing more of these cases may contribute significantly to medical knowledge about the clinical, diagnostic and therapeutic features of the disease in renal transplant recipients.

\section{Conflict of Interest}

No conflict of interest was declared by the authors.

\section{REFERENCES}

1. Antinori S, Cascio A, Parravicini C, Bianchi R, Corbellino M. Leishmaniasis among organ transplant recipients. Lancet Infect Dis, 2008; 8: 191-9.

2. De Rossell RA, de Duran RJ, Rossell $O$, RodriguezAM. Is leishmaniasis ever cured? Trans R Soc Trop Med Hyg, 1992; 86: 251.

3. Oliveira CM, Oliveira ML, Andrade SC, Girao ES, Ponte CN, Mota $\mathrm{MU}$, et al. Visceral leishmaniasis in renal transplant recipients: clinical aspects, diagnostic problems, and response to treatment. Transplant Proc, 2008; 40: 755-60.

4. Moroni G, Bossi L. Don't forget visceral leishmaniasis in transplant patients. Nephrol Dial Transplant, 1995; 10: 563-4.

5. Boletis JN, Pefanis A, Stathakis C, Helioti H, Kostakis A, Giamarellou $H$, 1999. Visceral Leishmaniasis in renal transplant recipients: successful treatment with liposomal amphotericin B (Ambisome). Clin Infec Dis, 28: 1308

6. Fernandez- Guerrero ML, Robles P, Rivas P, Mojer F, Muniz G, de Gorgolas M. Visceral leishmaniasis in immunocompromised patients with and without AIDS: a comparison of clinical features and prognosis. Acta Trop, 2004; 90: 11-6.

7. Sundar S, Rai M. Laboratory diagnosis of visceral leishmaniasis. Clin Diagn Lab Immunol, 2002; 9: 951.

8. Apaydin S, Ataman R, Serdengecti K, Tuzuner N, Polat E, Erek E, et al. Visceral leishmaniasis without fever in a kidney transplant recipient. Nephron, 1997; 75: 241-2.

9. Ersoy A, Gullulu M, Usta M, Ozçelik T, Ylmaz E, Uzaslan EK, et al. A renal transplant recipient with pulmonary tuberculosis and visceral leishmaniasis: review of superimposed infections and therapy approaches. Clin Nephrol, 2003; 60: 289-94.

10. Sabbatini M, Pisani A, Ragosta A, Gallo R, Borrelli F, Cianciaruso B. Visceral leishmaniasis in renal transplant recipients: is it stil a challenge to the nephrologist? Transplantation, 2002; 73: 299-301. 